\title{
Public Health System in Brazil nowadays: challenges for its operation and funding
}

\author{
Sistema Público de Saúde no Brasil na atualidade: os desafios para sua operacionalização \\ e financiamento
}

Sistema de Salud Pública en el Brasil de hoy: retos para su funcionamiento y financiación

Alethele de Oliveira Santos ${ }^{1}$

Sandra Mara Campos Alves ${ }^{2}$

\begin{abstract}
This paper has the aim to revisit the theme of the brazilian public health system from the perspective of its operation and funding of its actions and services, analyzing some of the main obstacles to its effectiveness. Endowed with its own logic of organization, planning and funding of its actions and services, the Brazilian Unified Health System (SUS) finds barriers to its sustainability when it comes to funding and the judicialization of health. Historical under-funding worsened by the economic and political crisis the country currently faces plus the increase in casuistic judicial decisions that prioritize the individual logic over the collective right have produced serious shocks in the system. These are just some of the challenges to an effective public health system. This is why the work of public bodies must be responsible and always take into consideration the collective dimension of the right to health under penalty of causing the collapse of the public health system altogether.
\end{abstract}

Keywords: Right to health. Unified Health System. Healthcare funding. Judicial decisions.

RESUMO: O artigo tem como objetivo revisitar o tema do sistema público de saúde brasileiro, a partir da perspectiva da operacionalidade e financiamento de suas ações e serviços, analisando alguns dos principais óbices à sua plena efetividade. Dotado de uma lógica própria de organização, planejamento e financiamento de suas ações e serviços, o Sistema Único de Saúde encontra, no financiamento e na crescente judicialização da saúde obstáculos à sua sustentabilidade. O subfinanciamento histórico agravado pela recente alteração constitucional que reduziu o aporte de verbas públicas, o panorama de crise econômica e política que atravessa o país, e o aumento de decisões judiciais casuísticas que prestigiam a lógica individual em detrimento do direito coletivo têm produzido severos abalos ao sistema público universal, são apenas alguns dos desafios à efetivação do sistema público de saúde. Por isso, a atuação dos poderes públicos deve ser responsável, e sempre com vistas à dimensão coletiva do direito à saúde, sob pena de conduzir o sistema público de saúde a um colapso.

Palavras-chave: Direito à saúde. Sistema Único de Saúde. Financiamento da Assistência à Saúde. Decisões Judiciais.

\footnotetext{
1 Doctorate Student in Collective Health at University of Brasilia (UnB), Lawyer, Technical Advisor to the National Council of Health Secretaries (Conass). Brasília - DF. Brazil. Email: alethele.santos@conass.org.br 2 Doctorate Student in Collective Health at University of Brasilia (UnB), Lawyer, Fellow Researcher and Professor in the Program of Health Law of Fiocruz Brasilia. Brasília - DF, Brazil. Email: smcalves@gmail.com
} 
RESUMEN: El artículo tiene como objetivo examinar la cuestión del sistema público de salud brasileño, desde el punto de vista del funcionamiento y la financiación de sus actividades y servicios, el análisis de algunos de los principales obstáculos para su plena efectividad. Equipado con su propia lógica de organización, planificación y financiación de sus actividades y servicios, el sistema de salud es, en la financiación y la creciente judicialización de los obstáculos para la salud de la sostenibilidad. La falta de financiación histórica agravada por la reciente reforma constitucional que reduce la contribución de los fondos públicos, las perspectivas de la crisis económica y política que atraviesa el país, y el aumento de juicios casuísticas que el prestigio de la lógica individual en detrimento de los derechos colectivos han producido conmociones cerebrales graves a las sistema público universal, son sólo algunos de los desafíos a la eficacia del sistema de salud pública. Por lo tanto, el papel del gobierno debe ser responsable, y siempre con vistas a la dimensión colectiva del derecho a la salud, en su defecto para dirigir el sistema de salud pública a colapsar.

Palabras-Ilave: Derecho a la salud. Sistema Único de Salud. Financiación de la Atención de la Salud. Decisiones Judiciales.

\section{Introduction}

In Brazil, the fight for the right to healthcare came strongly connected to the movement for re-democratization. In the VIII National Health Conference (VIII CNS) in 1986, the discussion on the right to healthcare was promoted, and included over 50 thousand people in a comprehensive debate on the Brazilian State (1).

In an attempt to portray what the VIII CNS meant in a few words, we resort to the memorable lesson by the sanitarian Sérgio Arouca (2):

The Brazilian Sanitary Reform was born of the fight against the Brazilian dictatorship with the theme Health and Democracy, and was organized in universities, within unions, in regional experiences of services that were organized. This social movement was cemented at the VIII National Health Conference in 1986, where, for the first time, over five thousand representatives of all areas of society discussed a new healthcare model for Brazil. The result was to ensure in the Constitution, by means of a popular amendment, that every citizen had the right to healthcare and the State should provide it.

The end of the authoritarian regime and the plea for welfare state were not sufficient to ensure an exclusively public healthcare system in Brazil. The Brazilian Constitution (3) establishes a mixed healthcare system, as determined by laws N. 8.080/1990 (4) and N. $8.142 / 1990$ (5) for the public system and law N. 9.656/1998 (6) for the supplementary system. 
This constitutional choice, even though dating back to almost 30 years ago, reveals the clear and permanent different existing interests and motivations in the creation of a national health system. Different administrations, party alignments, professional sector, private healthcare companies, the business, philanthropy and service sectors engage in putting the very pressure of capitalism.

Therefore, in practical terms, Brazilian legislation allowed the public (SUS) and private (supplementary) system to work in this sector, also allowing the private to work in the public (complementary) and the public in private (regulation, inspection, oversight) (7).

In this scenario, the Brazilian regulatory system considers healthcare to be a civil right that must be provided, which requires a positive conduct by the State for it to be implemented.

Thus, with regards to the State's concrete actions in positively implementing the law and providing its citizens with healthcare, the Brazilian public Unified Health System(SUS) must: fill in the vacuums of assistance - ignored by the business sector; lead the fight against epidemiological variations caused by outbreaks and epidemics; conduct technical and scientific research that receives little attention from the industry; regulate the professional qualification and training (as well educate, train and qualify different health professionals); take the lead in being the main care provider of ageing populations, the rising levels of violence and traffic accidents; and address the rising judicializaton.

These factors, despite not being exhaustive, constitute an aggravating scenario to the public health system planning, considering that the search for the adequacy of resources and sustainability is prior to its implementation and constitutes a perennial challenge (7).

In this context, this paper revisits the theme of the Brazilian Public Unified System (SUS), from the perspective of its operation and funding of its activities and services, analyzing some of the main obstacles to its full effectiveness.

\section{On the operation and funding of SUS}

The guiding principle SUS is the recognition of it being a civil right as established by the Constitution with all of its axiological charge, which determines that health be 'a right of everyone and a duty of the State, ensuring by means of social and economic policies that 
seek to reduce the risk of disease and other aggravating factors and to grant equal access to services for health promotion, protection and recovery' (1).

Hence SUS is required to have its actions and services integrated to the regional and hierarchical network, which are organized through the efforts of management and funding of the entities of the Federation (Union, States, the Federal District and Cities) (1). Its guidelines established by law (4) aim to ensure the operations of this system.

Regionalization is an essential pillar and an important aspect to ensure equality. In this perspective, each unit of the Federation is able to work the most efficiently and effectively on action to promote health, taking into consideration the specific characteristics inherent to each region.

Whereas the hierarchical framework of healthcare services and actions works as a way to guide the access by means of assistance flows, taking into account the several levels of attention and their respective technological density. In the Brazilian model, primary care was elected as the main entrance to SUS, with emphasis on the family health strategy with teams trained to take care of different populations and health situations.

Decentralization constitutes the tripod of SUS's organizing guidelines. It makes it possible for the authorities of each of Federation unit to manage the system in its respective territory thanks to the agreement on functions and responsibilities between each Government body.

These principles make SUS a system managed by the combination of management and resource efforts of the Union, the States, the Federal District (DF), and cities. The same happens with its funding.

The entities of the federation have in law N. 141/2012 (8) the indication of the minimum funding to be applied to health, which must be implemented according to the public health services (ASPS) and actions that must be supplied - items accepted as part of the revenue in this funding sector. Therefore, it points in general terms the composition of the State's positive offer of healthcare services.

SUS is the main population's care provider. It is present at all levels of care and has its own public services, university hospitals and even private services, which act to in a complementary way to Brazilian state.

In order to have a proper notion of the current structural and logistical size of SUS, according to its own information system for the registration of health facilities in Brazil, 
about 280,000 health institutions provide services to the public health system. Among these, approximately 200,000 are private (and non-profit) complementary service providers (9).

In summary, the relationships between management and funding of the Brazilian healthcare system are intertwined. A proof of this entanglement is that procedures which are quite costly to SUS - linked to specialized care - are more performed by the private sector (profit or non-profit). Consequently, the provision of health services registered in the national database system indicates that approximately $10 \%$ of procedures correspond to about $50 \%$ of the cost of federal funding (9) (10) (11).

To further show the robust logistics of SUS, it is worth mentioning its national database that collects information on health and sanitation concerning the territory and the Brazilian population. The development and maintenance of national database are essential to understand the health-disease process in contemporary society, and also stand for a strategic role in management, planning and assessment of public policies in the field of health (12).

The information on health generated by these data enables us to identify issues of public health in the individual and collective sphere, ranging from scientific knowledge on a given disease to a more comprehensive view of the health of a certain group in a certain territory (12) (13). These common tools in our current knowledge and information age are key to the decision making process of healthcare managers.

For instance, the National System of Health Facilities (SCNES) registers both private and public healthcare facilities in the country (profit or non-profit) that provide SUS with services (9).

Thus, these facilities have their provided services registered in the System of Hospital Information in SUS (SIH-SUS), which registers through the Authorization of Hospitalization (AIH) (10) and the System of Ambulatory Information (SIA-SUS) (11), whose registers occur through the Ambulatory Production Report (BPA) and/or the Authorization for High Complexity Procedures (APAC). However, it is important to point that the analysis of data of the these systems requires knowledge of their own regulations to the extent that in some cases there is record of all the services provided even though the consolidation of public funding comprises exclusively federal resources. 
These systems of information are able to reveal local, state, regional, and national realities, as well as the actions and services provided. Their data are essential for the management of SUS and can be analyzed together with the System of Information on Mortality (SIM) (14), the System of Information of Notification of Illnesses (SINAN) (15) and many other systems that contribute for managing health in such a large and complex country.

The operation of a universal public healthcare system in a continental territory required the development of participative, effective and distinct governance that includes the inter-managing commissions.

This model of governance, comprising an inter-federative arrangement, is established by Law N. 8.080 (4). Its deliberations occur at the national level by the Tripartite InterManagerial Committee (CIT); at the State level by the Bipartite Inter-Managerial Committee (CIB); and, at the regional level by the Regional Inter-Managerial Committee (CIR). These committees have been consolidating themselves as the central locus of discussion and decision making, strongly helping the implementation of the right to health within the scope of SUS. Hence they integrate the field of healthcare law as 'spaces for the genesis of rights' (p. 40) (16) due to their deliberative aspect.

In this sense, these deliberations start to build a legal framework that makes it mandatory for the State to supply with actions and services, though observing the rationalization of services and resources, competences and responsibilities of the entities of the Federal, also taking into account the public interest (16).

The norms that implement the guidelines, the constitutional and legal foundation of SUS have been represented since 1991 by the Norms of Basic Operations (17); and, since 2001, by the Norms of Operations in Health Assistance (18). In 2006, the representation also took place through the Health Pact in its three dimensions: for Life, in Defense of SUS and its Management (19).

More recently, these guideless were specified by the Decree 7.508/2011 (20), which regulates legislation on health (4), acting on the essential areas to the framework of SUS, on assistance to health and inter-federative work. It also established the Relation of Actions and Health Services (RENASES) and the National Relation of Medications (RENAME) which represent, respectively, the range of services and actions, and medications provided to the population by SUS. 
It can be noted, therefore, that the set of activities that supports the Brazilian healthcare system is complex, including a broad normative set that establishes the responsibility of each entity - in terms of management and funding - for the implementation of services that grant the right to health. There is inevitably a constant need to overcome obstacles.

Even if we consider the immense progress in terms of sanitation, epidemiology and policies brought by SUS to the population, challenges still remain and increase. The universal system finds barriers in the constitutional choice for segmentation and in a model that still does not adjust to the quickly changing characteristics of the population. It also lacks the necessary qualification of social participation, and faces difficulties related to work management, growing judicialization, and in the pursuit of sustainable funding.

Since it is impossible to address all these factors here, we choose to make brief comments on funding, judicialization of the right to health and the relation between both.

\section{Funding as a challenge to the management of SUS}

Endowed with its own logic of organization, planning, and funding, SUS is currently found in an unfavorable context concerning its most essential aspect - funding. This may jeopardize the continuity of a series of actions and services, as well as prevent the start of new projects (7).

In a scenario where there is desire to believe in the autonomy of management, in its capacity to innovate and achieve satisfactory results, we need to take into account that this same management - in the case of SUS - is not supported by adequate and sustainable funding. The under-funding of SUS is historical and has been worsening each day.

This situation presented here is corroborated by studies on the under-funding of the public healthcare sector, federal funding, and the percentage invested by States and cities (21). Therefore, it is not feasible to compare the reach of SUS with other universal system because the allocation of resources in the Brazilian system does not reach $4 \%$ of the country's GDP.

In this context, the year of 2015 was marked by the prevalence of facts that came to aggravate this scenario, including changes in the constitutional text altering an already 
previously insufficient funding model and reducing the allocation of public funding in the universal and free public healthcare system (21).

In 2016, the situation did not change that much. In a recent paper, Bahia (22) states that in the world healthcare public investment has been enhanced, whereas in Brazil, federal expenditures have been kept stable despite changes in the population profile. $\mathrm{He}$ also warns about the impact of the economic recession on the health system, since it is linked to the country's revenues.

Add to this scenario the large number of people who used to have a private health insurance (supplementary system), but recently, have come to rely exclusively on the public system. Data from the Institute of Studies on Supplementary Health (23) show that in the period of March 2015 to March 2016, over 1,331,924 contracts were terminated.

In the same period, it was observed that the whole growth rate of contract beneficiaries became negative: a) total collective health insurance: $-2.64 \%$; b) business collective health insurance: $-2.66 \%$; c) collective insurance by agreement: $-2.50 \%$; d) individual health insurance: $-2.29 \%(23)$.

In this severely atypical year to Brazil in terms of political and economic stability, the interim government has presented to the Congress a project of constitutional amendment N. 241/2016 (24) in the name of the new Fiscal Regime for Brazil. This project intends to establish the basis for a structural fiscal adjustment of public expenditures by legally preventing an increase in public expenditure for 20 years, allowing its revision in the $10^{\text {th }}$ year. Even though there is no consensus on the losses for the welfare state, there is indication that the more the country grows, the less the health system will receive. Such project has a serious impact on the right to public health services, entailing the need to carefully its discussions and developments in the Brazilian legislative branch.

In truth, the discussion thereby presented is that of economic growth and fiscal balance against the assurance of the right to health. In this sense, it cannot be ignored that health is a means to promote the reduction of inequality and injustice. In Bahia's words (22):

To be in favor of fiscal balance does not mean to make economic growth and social and human development opposite to each other. The essential question is to define if the resulting resources of the equation of less debt and lower interest rates will make more investments return to the progressive well being or if they will only serve to further injustice. 
As the right to health is an issue that overlaps among the three branches, we cannot ignore matters relating to the Judiciary branch. For being a sensitive issue, the funding of SUS is not something to be overlooked by the Judiciary Branch. The Constitutional Court in 2009 made a significant decision by suspending a summary judgment motion (STA) (25), clearly showing the importance of public funding for attaining universal coverage.

The Unified System of Health is based on public funding and on universal coverage of actions in health. In this way, for the State to ensure the functioning of the system, it is necessary to take into account the stability of expenditures with health, and, consequently, of investments.

Yet, this remains a major challenge in the unified Brazilian system, especially nowadays due to the growing phenomenon of health judicialization that ensures rights on one hand, but unbalances the funding logic on the other.

\section{The judicialization of the right to health as a challenge to the management of SUS}

Even recognizing the difficulties of financial sustainability SUS faces, the Judiciary branch, in its relation to the positive provision of services as determined by law, often is the cause of such difficulties and changes in its operational logic. This happens in the case of casuistic decisions that don't just cause financial losses, but also weaken the laws concerning health by not taking into account the normative agreements established between the various deliberative instances (26).

When we consider the work of the Judiciary branch on matters of health, it is part of the individual and collective rights as established by the Federal Constitution, a pillar of the democratic thought and the Rule of Law. Therefore, such work needs to be as competent and reasonable as possible.

This requires that judicial actions do not superimpose a logic alien to the existing one for SUS, respecting its principles and not jeopardizing its planning, structure, control, and funding.

The judicialization of the right to health calls for the analysis of its causes - generally of collective nature - and not only of its consequences - granting the individual right. In the 
analysis of arrest warrants of a SUS manager who did not comply with judicial decisions, this concern is well exemplified by Schulze (27):

\begin{abstract}
Very often judges issue decisions with urgency - injunctions and summary judgments. This is a controversial theme because some medical doctors say that there is not urgency in matters relating to the right to health, except for a few hypotheses [2]. But the main point is: can a manager carry out a decision that fixes a $24 \mathrm{~h}, 48 \mathrm{~h}$ or $72 \mathrm{~h}$ deadline? It is hardly possible, especially when it involves importing a certain product or medication even when the bidding has been dismissed (and here we have another problem, since the possible absence of competition may result in overpricing). The same can be verified in relation to orders of hospitalization. If there is a lawsuit, it is because there is not enough vacancy. In this case, practice has shown that the manager draws tow lists - one for complying with injunctions and another for patients who are waiting without a lawsuit (who possibly will be damaged, violating the principle of isonomy). Hence there can only be an improvement with the increase of rooms and beds.
\end{abstract}

Measures have been taken for SUS not to be seen by society or any of the powers instituted as a mere "provider" of procedures and medications. To corroborate this, the National Justice Council (CNJ) has recently issued a public statement in a wide circulation Brazilian newspaper about the need to respect the logic of SUS, and the constitutional text, as well as the agreement between managers. In the words of Counselor Arnaldo Hossepian (28):

In this context, the $\mathrm{CNJ}$ forum wishes to contribute with the development of criteria that guide jurisdictional activity so as to avoid that the legitimate intention to ensure citizens' right to health results in the disruption of system, either public or private. These criteria should, therefore, aid judges in identifying and accepting legitimate demands and rejecting abusive demands. In this way, we can better use the potential of this right to provide citizens with effective access to quality health services, and at the same time, encourage the system to correct omissions and improve public policies. To fulfill this goal, it is necessary to rethink the dominant interpretation among jurists on the constitutional directive of integrality in health, comparing the constitutional text with the public policies developed by the Legislative branch, and, above all, by SUS managers at the federal, state and city level.

To depict the vast range of interests that the health sector comprised, Law $\mathrm{N}$. 13.269/2016, issued by Congress and approved by the Executive, enforces the national registration and supply by the public system of the substance called phosphoethanolamine without properly complying with the scientific method and the regulatory national agency. 
The constitutionality of this piece of legislation was taken to the analysis of the Judiciary, which will have the last say on this (29).

Another relevant example under scrutiny of the Judiciary is the Mais Médicos (More Doctors) Program (Law N. 12.871/2013). It's an initiative developed by the Executive branch that aims to fill in the vacuum of health services in vulnerable regions by bringing Brazilian and foreign doctors to these high priority places. Its constitutionality has been questioned by the Brazilian Medical Association, The Federal Council of Medicine, and the National Confederation of Liberal and University Workers, especially when it comes to allowing medical practice by foreigners. It is still awaiting judgment. (30) (31)

As these, there are many other cases, in which the Judiciary's decision will greatly impact on SUS, either in administrative or financial terms. It is important to note that these are cases which go beyond the individual dimension of the right to health, since they really show the dimension of health as a social and collective right as it is established in the Constitutional text.

In this sense, it is important for the Judiciary branch to be aware of the content of its decisions because it will be responsible for defining important routes to SUS, and, consequently, to the very implementation of health public policies.

\section{Final Considerations}

It might be too simplistic to describe Brazilian society as binary, but this is how it presents itself. It admires democracy, but also utters positions that are typical of authoritarian regimes; it has periods of strengthening of the working class and rules for the industry based on neoliberal economics; it values universal public policies and accepts fiscal cuts for the private initiative. Even so, people demand from public powers a response that is compatible to an increasingly complex society in a continental territory, and with diverse cultures.

When it comes to the right to health in Brazil, there is the possibility of such positive provision to be available in access and use with or without the imposition of conditions to the individual. In both cases, the access to actions and health services is linked with funding - from public policies to public funding; in private health assistance, from direct payment to hiring insurance. 
The Brazilian experience prior to the last thirty years showed that the right to health by means of financial contributions was not capable of responding to social needs, aggravating injustice in the country if compared to other nations. Reality has shown that a logic that is beneficent to the market is solely able to place the less economically favored individuals under charity care.

With the adoption of the principle of solidarity - in which all of society funds the costs of fundamental rights - the right to health in Brazil attained the status of universal politics. However, not even the Federal Constitution was able to ensure its financial sustainability.

The growing demand for accessible and high quality health actions and services, reflected both by the health indicators, and the amount of lawsuits, exposes the existing relation between the social right to health, economic performance, and public rationality.

It is in this social reality that SUS struggles to survive and effectively respond to the positive provision of the right to health. Therefore, the defense of SUS imposes a social reaffirmation of the right to universal health - an egalitarian, integral and free of privilege system.

It is necessary to note that the irresponsible behavior of the three public branches may lead SUS to collapse.

\section{References}

1. Brasil. Ministério da Saúde. Relatório final da VIII Conferência Nacional de Saúde. Brasília, 1986. Available at: http://bvsms.saude.gov.br/bvs/publicacoes/8_conferencia_nacional_saude_relatorio_final.p df [Last access on 20 june 2016]

2. Arouca S. A reforma sanitária brasileira. Tema, Radis, n.11, p.2-4, 1998.

3. Brasil. Constituição da República Federativa do Brasil de 1988. Available at: http://www.planalto.gov.br. [Last access on 27 june 2016]

4. Brasil. Lei 8.080/1990. Available at: http://www.planalto.gov.br/ccivil_03/leis/L8080.htm. [Last access on 27 june 2016]

5. Brasil. Lei 8.142/1990. Available at: http://www.planalto.gov.br/ccivil_03/leis/L8142.htm. [Last access on 27 june 2016]

6. Brasil. Lei 9.656/1998. Available at: http://www.planalto.gov.br/ccivil_03/leis/L9656.htm. [Last access on 27 june 2016] 
7. Santos AO, Delduque MC, Alves SMC. Os três poderes do Estado e o financiamento do SUS: o ano de 2015. Cad. Saúde Pública; 32( 1 ): e00194815. Available at: http://www.scielo.br/scielo.php?script=sci_arttext\&pid=S0102311X2016000100301\&lng=pt. Epub 12-Fev-2016. http://dx.doi.org/10.1590/0102$311 \times 00194815$ [Last access on 27 june 2016]

8. Brasil. Lei Complementar à Constituição Federal n. 141/2012. Available at: http://www.planalto.gov.br/ccivil_03/leis/LCP/Lcp141.htm. [Last access on 27 june 2016]

9. Brasil. Ministério da Saúde. Sistema de Cadastro Nacional de Estabelecimentos de Saúde. Available at: http://datasus.saude.gov.br/sistemas-e-aplicativos/cadastrosnacionais/scnes. [Last acess on 08 apr 2016]

10. Brasil. Ministério da Saúde. Sistema de Informações Hospitalares no SUS. Available at: http://datasus.saude.gov.br/sistemas-e-aplicativos/hospitalares/sihsus. [Last access on 08 apr 2016]

11. Brasil. Ministério da Saúde. Sistema de Informações Ambulatoriais do SUS. Available at: http://datasus.saude.gov.br/sistemas-e-aplicativos/ambulatoriais/sia. [Last access on 08 apr 2016]

12. Alves SMC. Os sistemas de informação de saúde no Brasil e o direito à intimidade. Cadernos Ibero-Americanos de Direito Sanitário. Brasília, v. 3, n.1, jan./jun. 2014, p. 84-93. Available at: http://www.cadernos.prodisa.fiocruz.br/index.php/cadernos/article/view/20/43. [Last access on 05 july 2016]

13. Dallari SG. A justiça, o direito e os bancos de dados epidemiológicos. Ciência \& Saúde Coletiva. 2(3), 2007, p.633-641

14. Brasil. Ministério da Saúde. Sistema de Informações sobre Mortalidade. Available at: http://portalsaude.saude.gov.br/index.php/o-ministerio/principal/secretarias/svs/mortalidade. [Last access on 05 july 2016]

15. Brasil. Ministério da Saúde. Sistema de Informações de Notificação de Agravos em Saúde. Available at: http://sinan.saude.gov.br/sinan/. [Last access on 05 july 2016]

16. Leão TM, Dallari SG. O poder normativo das Comissões Intergestores Bipartite e a efetividade de suas normas. Revista de Direito Sanitário. São Paulo, v.17, n.1, mar./jun. 2016, p. 38-53

17. Scatena JHG, Tanaka OY. Os instrumentos normalizadores (NOB) no processo de descentralização da saúde. Available at: http://webcache.googleusercontent.com/search?q=cache:rd-

gy6824IMJ:www.scielo.br/pdf/sausoc/v10n2/05.pdf+\&cd=9\&hl=pt-

$\mathrm{BR} \& c t=c \mid n k \& g l=b r \& c l i e n t=f i r e f o x-b-a b$. [Last access on 05 july 2016] 
18. Brasil. Ministério da Saúde. Normas Operacionais de Assistência à Saúde. Available at: http://bvsms.saude.gov.br/bvs/saudelegis/gm/2002/prt0373_27_02_2002.html. [Last access on 05 july 2016]

19. Brasil. Ministério da Saúde. Pacto pela Saúde. Available at: http://webcache.googleusercontent.com/search?q=cache:TdB8eZ8BejAJ:conselho.saude.g ov.br/webpacto/index.htm+\&cd=1\&hl=pt-BR\&ct=clnk\&gl=br\&client=firefox-b. [Last access on 27 june 2016]

20. Brasil. Decreto 7.508/2011. Available at: http://www.planalto.gov.br/ccivil_03/_ato2011-2014/2011/decreto/D7508.htm. [Last access on 27 june 2016]

21. Brasil. Conselho Nacional de Secretários de Saúde. Available at: http://www.conass.org.br/consensus/o-esgotamento-modelo-de-financiamento-sus/. [Last access on 22 june 2016]

22. Bahia L. Fica, SUS. O Globo. Rio de Janeiro. 4 de julho de 2016. Available at: https://www.abrasco.org.br/site/2016/07/fica-sus-artigo-de-ligia-bahia/ [Last access on 06 june 2016]

23. Instituto de Estudos de Saúde Suplementar. Saúde Suplementar em Números. Edição no $11,2016$.

Available at http://documents.scribd.com.s3.amazonaws.com/docs/2g8ezh06rk58nymo.pdf [Last access on 06 june 2016]

24. Brasil. Projeto de emenda constitucional n. 241/2016. Available at: http://www.camara.gov.br/proposicoesWeb/fichadetramitacao?idProposicao=2088351. [Last access on 26 june 2016]

25. Brasil. Supremo Tribunal Federal. Available at: http://www.stf.jus.br/arquivo/cms/noticianoticiastf/anexo/sta175.pdf. [Last access on 26 june 2016]

26. Stival SLM, Girão F. A judicialização da saúde: breves comentários. Cadernos IberoAmericanos de Direito Sanitário. Brasília, v.5, n. 2, abr./jun. 2016, p. 141-158. Available at: http://www.cadernos.prodisa.fiocruz.br/index.php/cadernos/article/view/285 [Last access on 03 june 2016]

27. Schulze CJ. Judicialização da saúde e prisão de gestor. Available at: http://emporiododireito.com.br/judicializacao-da-saude-e-prisao-de-gestor/. [Last access on 03 june 2016]

28. Hossepian Júnior AL. Justiça garantia de saúde. Available at: http://www1.folha.uol.com.br/opiniao/2016/06/1785041-justica-garantia-de-saude.shtml . [Last access on 13 july 2016] 
29. Brasil. Supremo Tribunal Federal. Available at:

http://www.stf.jus.br/portal/cms/verNoticiaDetalhe.asp?idConteudo=317011. [Last access on 13 july 2016]

30.Silva SM, Santos LMP. Estudo das ações diretas de inconstitucionalidades do Programa Mais Médicos. Cadernos Ibero-Americanos de Direito Sanitário. Brasília, v.4, n. 2, abr./jun. 2015, p. 68- 82. Available at: http://www.cadernos.prodisa.fiocruz.br/index.php/cadernos/article/view/154 [Last access on 13 july 2016]

31. Cerqueira JP, Alves SMC. A constitucionalidade do Projeto Mais Médicos para o Brasil. Cadernos Ibero-Americanos de Direito Sanitário. Brasília, v.5, n. 2, abr./jun. 2016, p. 91107. Available at:

http://www.cadernos.prodisa.fiocruz.br/index.php/cadernos/article/view/249 [Last access on 13 july 2016]

\section{Como citar este artigo:}

Santos AO, Alves SMC. Public Health System in Brazil nowadays: challenges for its operation and funding. Revista Cadernos Ibero-Americanos de Direito Sanitário. 2016 jul./set, 5(3):65-79. 